\title{
State of Individual Health, Cardiorespiratory System of Junior Schoolchildren in the Far North with Different Temperament Trait Indices
}

\author{
Yaroslavna V. Bardetskaya and Vasilina Yu. Potylitsyna* \\ Krasnoyarsk State Pedagogical University \\ named after V.P. Astafev \\ 89 Ada Lebedeva Str., Krasnoyarsk, 660049 Russia
}

Received 24.03.2015, received in revised form 17.08.2015, accepted 20.09.2015

\begin{abstract}
The article presents an integrative health assessment with measurement of the indices of santiveness and pativeness, studies heart rate variability (HRV) and respiratory function in junior schoolchildren if the Far North with different temperament trait indices. It was found that junior schoolchildren in the Far North had an interrelation between typological characteristics of temperament and the standard of health, mechanisms of regulation of cardiac rhythm and functional indices of external respiration. Junior schoolchildren in the Far North, whose temperament is characterized by the low intensity of behavioural symptoms, have higher adaptive reserves, functional indices of external respiration and predominant parasympathetic influence in the regulation of heart rate. Thus, the results of the study have shown that the formation of temperament types occurs in the early school years, which may affect the efficiency of adaptive reactions of children living in the Far North and the state of their personal health.
\end{abstract}

Keywords: temperament, junior schoolchildren in the Far North, standard of health, cardiorespiratory system.

The Study Was Conducted as Part of the Grant RGHF 15-16-24007 Entitled "Comprehensive Studies of the Indigenous Peoples of the Arctic Zone of Eastern Siberia in Basic Medicine, Remote Pedagogy, Socio-Cultural and Economic Activities".

DOI: 10.17516/1997-1370-2015-8-11-2220-2232.

Research area: pedagogy, psychology.

Children in the Far North are the most socially vulnerable group of the population living in particularly difficult conditions, which adversely affects their health and development, so these facts require detailed study and the need to consider a number of natural and climatic factors that directly affect the adaptation mechanisms of a growing organism.

It is well known that adverse biological, medical, social, psychological and other factors are the main predictors of pathologies in cardiovascular, respiratory, nervous, endocrine and other systems (Tokarev S.A., Buganov A.A.,

C) Siberian Federal University. All rights reserved

* Corresponding author E-mail address: vptcn@yandex.ru, byvkgpu@yandex.ru 
2007). In addition, in the Far North the health and development of the younger generations are affected by the uncontrolled climatic, geographic and biosocial factors that are typical of the high-latitude regions and have particular harmful effects on the child's body and help to speed up the formation of pathology. There is evidence that in the extreme conditions of the circumpolar region, the cumulative effect of the above factors has a significant impact on the effectiveness of adaptation and potential on the public health (Shesterikova N.V., Tokarev S.A., 2004).

According to the statistics and the results of scientific research, over the past decade the state of health of children in the Russian Federation has undergone significant adverse changes (Kuchma V.R., Zvezdina I.V., Zhigareva N.S., 2008; Baranov A.A., Kuchma V.R., Rapoport I.K., 2011). They are characterized by the increasing prevalence of functional disorders and chronic diseases that are particularly pronounced in the period of schooling (Igisheva L.N., 2008; Baranov A.A., Kuchma V.R., Sukhareva L.M., 2009). Health problems at the high school age are largely determined by the influence of behavioural risk factors: smoking, drinking, physical inactivity, etc. (Chekalova S.A., Bogomolova E.S., Leonov A.V., Kuzmichev Iu.G., Chekalova N.G., Nazarova M.M., 2009; Maiorov R.V., 2012; Slobodskaia E.R., Akhmetova O.A., Kuznetsova V.B., Rippinen T.O., 2012; Varshal A.V., Slobodskaia E.R., 2013). At the same time, the high frequency of disorders in the health of junior schoolchildren currently defines the need to study medical, psychological and social aspects of its formation during elementary school attendance (Savilov E.D., Il'ina S.V., 2012; Kondakova O.E., Gezalova N.V., Shilov S.N., Kozhevnikov V.N., 2013).

The beginning of school is a powerful stress factor that changes the way of life of children, their order of the day, timetable of lessons and recreation (Chekalova N.G., Silkin Yu.R., Shaposhnikova M.V., Chekalova S.A., Bogomolova E.S., Glushenkova D.A., Shcherbaneva M.S., 2009; Dziatkovskaia E.N., 2011). The change of the dynamic stereotype leads to stress of adaptation mechanisms and reduction of functionality of schoolchildren's organisms, which is worsened by the influence of unfavourable factors, including the lifestyle related. At this, the main factor causing disorder of mechanisms of self-regulation of individual functional systems of junior schoolchildren with the subsequent development of chronic diseases is often a psycho-emotional stress (Slobodskaia H.R., Akhmetova O.A., 2010; Iliukhina V.A., 2011; Verkhoturova N.Yu., 2012, Il'ina I.V., 2012).

At present, the ideas of temperament traits are explained by differences in the excitability of the brain systems that integrate the behaviour of the individual, his emotions and vegetative functions (Potylitsyna V.Yu., 2008; Petrosian E.Iu., Savchenkov Iu.I., 2009; Riasik Iu.V., Tsirkin V.I., Trukhina S.I., 2010; Khabarova I.V., Shilov S.N., 2012). Both systems cause autonomic mobilization (Savchenkov Iu.I., Soldatova O.G., Shilov S.N., 2013), which largely, in our opinion, explains the adaptive role of temperament.

Circulatory and respiratory systems have a leading role in the adaptive responses of the body when it is exposed to the influence of a variety of factors, ensuring the necessary level of energy and metabolic processes. The cardiorespiratory system is one of the first to get involved in the process of adaptation of the organism to changing environmental conditions and its changing settings may serve as criteria for the effectiveness of adaptive responses (Shlyk N.I., Sapozhnikova E.N., Kirillova T.G., Semenov V.G., 2009; Mikhailov N.A., 2011; Kushnir S.M., Struchkova I.V., Makarova I.I., Antonova L.K., 2012; Ushakov I.B., Orlov O.I., 
Baevskii R.M., Bersenev E.Iu., Chernikova A.G., 2013).

Therefore, the question about the features of the functional state of breathing, heart rate regulation and the standard of individual health of junior schoolchildren in the Far North with different indices of temperament traits is of an undoubted scientific interest.

The aim of our research is to carry out a quantitative evaluation of individual health and determine the state of the cardiorespiratory system of junior schoolchildren in the Far North with different indices of temperament traits.

Almost healthy junior schoolchildren in the Far North were tested to determine the type of temperament by means of a parental questionnaire DOTS-R (The Revised of Temperament Survey) adapted for Russia. This technique presents the possibility of accurate quantification of 9 temperament traits of children. The identification of temperament types was conducted by the behaviour index (BI), which includes such temperament features as activity, sensitivity (threshold), mood and intensity, and by the behaviour stereotype strength index (BSSI), which is the sum of quantitative indices of rhythm and adoptability (Petrosian E.Iu., Savchenkov Iu.I., Domracheva M.Ia., Domrachev A.A. Patent of the Russian Federation IPC 7A 61 in 5/16; Petrosian E.Iu., Savchenkov Iu.I., 2009). All the children were divided into groups by $\mathrm{BI}$; into "intense" (In), "adequate" (Ad) and "quiet" (Q) and by BSSI: into "rigid", "plastic" and "labile", respectively, with high, middle and low index values.

All the junior schoolchildren in the Far North were tested by the following indices: heart rate (HR), systolic and diastolic blood pressure (SBP, DBP), vital capacity (VC), hand power; veloergometry cardiointervalography (by the diagnostic complex "VALENTA"), Stange's test (test of timed inspiratory capacity), Rufe's test (heart rate recovery time after dosed physical load). The obtained data was processed by a computer program "HELMI-test of 7-10 yearold children" (Kulikov V.P., Bezmaternykh L.E., Kozlov S.D.) and was presented in the form of opinions on the index of santiveness - health potential that determines its probable quantity and quality (PS) and pativenesses - the probability of the disease, limitation of viability (PP).

Heart rate variability (HRV) and respiratory function were studied by a hardware-programmed complex "VALENTA". The following indices of heart rate were recorded and evaluated: heart rate (HR), tension index of regulatory systems (stress index, TI), Mo - mode, AMo - mode amplitude, the average value of the power of spectrum of a high-frequency component of heart rate variability (BV), the average value of the power of spectrum of a low-frequency component of heart rate variability (SV-2) and of a very lowfrequency component of heart rate variability (SV-1), the number of pairs of cardio intervals with difference of more than $50 \mathrm{~ms}$ in $\%$ to the total number of cardio intervals in the array (pNN50), and also the centralization index (CI) in rest and in a clinoorthostatic test.

In order to assess a respiratory function such indices as forced vital capacity (FVC), forced expiratory volume $\left(\mathrm{FEV}_{1}\right)$, peak volume rate (PVR), forced expiratory rate at $25-75 \%$ of forced vital capacity (FEV25-75\%), minute ventilation $(\mathrm{MV})$, respiratory rate (RR), maximum ventilation (MV), Tiffeneau index were recorded.

According to different indices of behavioural responses, $51 \%$ of the surveyed children in the Far North showed the average values. "Intense" and "quiet" children were identified in equal numbers. By the strength of the formed stereotypes 50\% of the children were included in the group of "plastic" children; the other kids in almost equal parts were included in the groups of "labile" (25.7\%) and "rigid" (23.8\%) children. 
The analysis of the integrative index of health established that the tested junior schoolchildren in the Far North on the average had an index of santiveness that did not exceed $60 \%$. This indicates a moderate reserve of their health, rather high probability of disease development (Soldatova O.G., Shilov S.N., Potylitsyna V.Yu., 2008). At the same time "quiet" children, both boys and girls, had an index of santiveness higher than the "adequate" and "intense" groups, which proves a greater reserve of their health and adaptive capacity in comparison with other groups of the tested children in the Far North.

The "quiet" children had a moderate index of reliable negative correlations (correlation coefficient from 0.38 to 0.48 ) of the index of santivenesswithtemperamenttraitscharacterizing behavioural activity and approach. The index of santiveness of "intense" junior schoolchildren had reliable negative correlations with rhythm, attention and, what is interesting, the behaviour index.

Our studies of integrated health indices show that junior schoolchildren in the Far North have low reserves of health, and therefore a significant probability of disease development (Bardetskaya Ya.V., Potylitsyna V.Yu., 2013). It is important that the reserves of health may be provided not only by the functional capacity of cardio-respiratory and other systems of the body, but also by the intensity of the child's personality temperament traits, especially of those that characterize behavioural activity. Health reserve depends on the index of the child's personality temperament traits, especially those that characterize behavioural activity. The children in the Far North whose temperament is characterized by a low behaviour index ("quiet") have a more favourable level of the body's functioning. Their health potential is higher than that of the "intense" children with distinct temperament traits that characterize the activity of behaviour.
In this case, the strength index of behavioural stereotypes in the characteristic of temperament traits of the child's personality in the studied age period, are apparently still not fully formed, so they have only a small influence on the adaptive capacity of the organism, as well as on the quantitative parameters of health.

The analysis of the main hemodynamic indices in the groups of junior schoolchildren in the Far North with different temperament trait indices characterizing the activity of the behaviour revealed a reliably higher initial autonomic level for boys and girls with high BI compared to "quiet" and "adequate" children. In the groups of children with different plasticity of behaviour we did not detect any differences in the basic hemodynamic indices.

In the analysis of heart rate variability at rest we found that there were some differences in the studied indices in the groups of the children in the Far North that differ in BI. Thus, the "quiet" children had lower mode amplitude and stress index, reduced power of SV-1, more pairs of cardio intervals with difference of more than 50 $\mathrm{ms}$ in $\%$ of the total number of cardio intervals in the array and a bigger power of BV and SV-2 compared with the "intense" children.

The findings indicate the prevalence of a parasympathetic component of autonomic regulation in children with a "quiet" temperament type. As the dominance of a parasympathetic component of the regulation indicates a more efficientandeffectiveleveloffunctioningofthebody and adaptation processes (Kulikov V.P., Doronina N.L., Gatalskii K.K., 2008; Khuraskina N.V., Aleksandrova L.A., Chemerova L.F., 2010; Kolpakov V.V, Bespalova T.V., Tomilova E.A., Larkina N.u., Mamchits E.V., Chernogrivova M.O., KopytovA.A.,2011;Bardetskaya Ya.V.,Potylitsyna V.Yu., 2014), we can say that children with a low index of behavioural symptoms are characterized by a more favourable functional capacity of the 
cardiovascular system. There were no significant differences in heart rate variability at rest in children with different plasticity of behaviour.

It is well known that children and adolescents, regardless of age, sex, place of residence, have individual typological features at the level of maturity of regulatory systems, especially of the cardiovascular system. We identified 4 groups with reliable quantitative and qualitative differences in the indices of heart rate variability characterizing different degrees of tension and interaction between the sympathetic and parasympathetic parts of the autonomic nervous system, autonomous and central control loops of the heart rhythm. The first group, according to the authors (Sapozhnikova E.N., Shlyk N.I., Shumikhina I.I., Kirillova T.G., 2012), are the children with high activity of a sympathetic part of the autonomic nervous system and the central levels of regulation, the second group consists of the children with high activity of a sympathetic part of the autonomic nervous system and a low degree of tension of the central levels of control, the third group includes the children with high activity of a sympathetic part of the autonomic nervous system, increased activity of the central regulatory systems and low activity of a sympathetic part of the autonomic nervous system, the fourth group are those with high activity of a parasympathetic part and low activity of a sympathetic part and central structures of heart rate regulation. The most optimal ratio between the autonomous and central regulation of heart rate is observed in children of the third group; exactly these children have the highest functional reserves of the system of regulation of blood circulation. The first group with predominance of the central mechanisms of control was attributed by the authors to an unfavourable rate.

When dividing the examined children in the Far North into groups with quantitative and qualitative differences in the indices of heart rate variability, we found that the highest percentage of the children of the third, optimal, group of autonomic regulation of heart rate fall into the category of "quiet" boys and girls while the least percentage of the same children are among the "intensive" (Fig. 1). In the groups of children that differ in the index of strength of
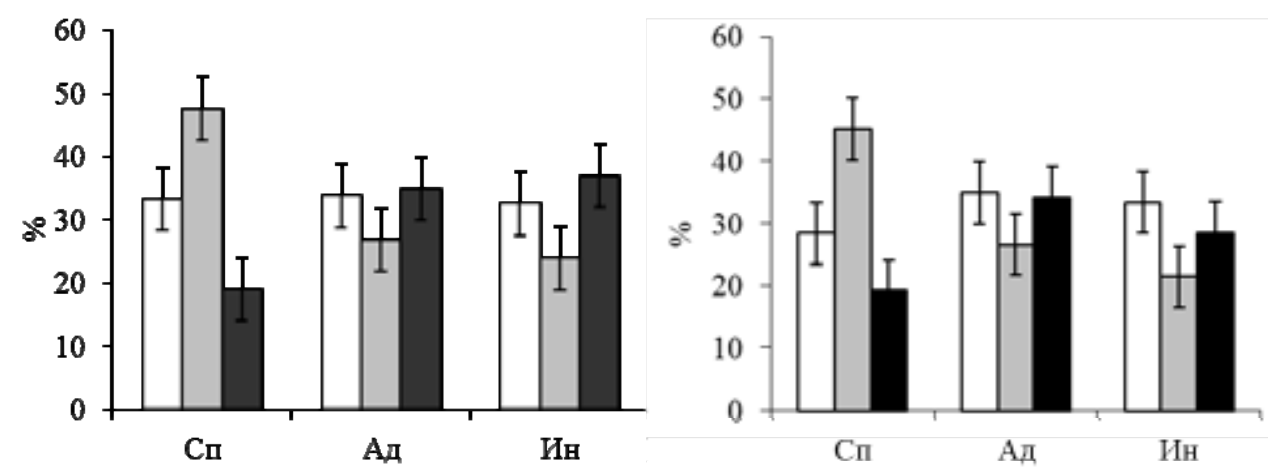

Fig. 1. Occurrence of groups with characteristics of regulation of heart rate in groups of "quiet" $\left(C_{\Pi}-Q\right)$, "adequate" (Ад - Ad) and "intensive" (Ин - In) boys and girls; $\square-$ children with high activity of a sympathetic part of the autonomic nervous system and a low degree of tension of the central levels of control, a - children with high activity of a parasympathetic part of the autonomic nervous system, increased activity of the central regulatory systems and the low activity of a sympathetic part of the autonomic nervous system, $\mathbf{m}-$ children with high activity of a parasympathetic part and low activity of a sympathetic part and central structures of heart rate regulation 
developed behaviour stereotypes the occurrence of an optimal balance between the autonomous and central regulation of heart rate is almost the same.

In assessing autonomic reactivity it was revealed that the "quiet" junior schoolchildren in the Far North with a low index of behavioural symptoms in a reliably greater percentage of the cases have initial vagotony and hypersympathicotonic reaction during functional load (Table 1). The children who belong to the "intense" group have a hypersympathicotonic reaction recorded in a smaller percentage of cases, which indicates a high initial tonus of the sympathetic nervous system, and as a consequence the absence of its additional activation during the transition to a vertical position.

In the groups of children varying in the strengthindex of developed behaviourstereotypes, the differences in autonomic reactivity were not revealed.

The correlation analysis of the relationship of the indices of heart rate variability and the index of temperament traits revealed their lack in "adequate" children, while there are reliable correlations between the indices of heart rate variability and the index of temperament traits in the case of the "intense" and "quiet" junior schoolchildren in the Far North (Table 2).

The significant $(\mathrm{p}<0.05) \quad$ correlations $(0.5<r>0.7)$ of the index of temperament traits with the indices of heart rate variability (TI, SV$1, \mathrm{BV}, \mathrm{SV}-2)$ in children with different plasticity of behaviour were identified only in the group of "labile" children; in case of boys in this group, these correlations have such features of temperament as threshold, mood and approach, while the girls' correlations have mood, attention and distractibility (Potylitsina V.Iu., Bardetskaia Ia.V., 2013).

In the analysis of the indices of respiratory function in groups of junior schoolchildren in the Far North with different temperament traits indices some differences were also identified. Thus, the respiratory rate of "quiet" children is less than that of the "intensive" ones, while the minute ventilation and the maximum ventilation rate are reliably higher than that of children of the "intensive" type. In the groups of children with different strength of developed stereotypes the "plastic" children are characterized by more optimal indices of the respiratory function.

The obtained results show a more optimal functioning of ventilation of junior schoolchildren

Table 1. Autonomic reactivity of junior schoolchildren in the Far North with different index of behaviour manifestations in a clinoorthostatic test

\begin{tabular}{|l|c|c|c|c|}
\hline \multirow{2}{*}{ Groups } & \multirow{2}{*}{$\mathrm{n}$} & \multicolumn{3}{c|}{ Autonomic reactivity (occurrence, \%) } \\
\cline { 3 - 5 } & & Asympathicotonic & Normal & Hypersympathicotonic \\
\hline \multicolumn{5}{|c|}{ Boys } \\
\hline Q & 55 & 4.1 & 39.8 & 56.1 \\
\hline Ad & 128 & $14.5^{*}$ & 36.4 & 49.1 \\
\hline In & 57 & $32.1^{*, \#}$ & 40.9 & $27.0^{*, \#}$ \\
\hline \multicolumn{5}{|c|}{ Girls } \\
\hline Q & 66 & 4.9 & 36.8 & 59,2 \\
\hline Ad & 140 & $11.2^{*}$ & 37.3 & $34.9^{*, \#}$ \\
\hline In & 67 & 32.9 & 32.1 & \\
\hline
\end{tabular}

Note: difference is reliable at $\mathrm{p}<0.05$ : * from the group of "quiet" children, \# - from the group of "adequate" children. 
Table 2. Correlation coefficients of heart rate variability and index of temperament traits of junior schoolchildren in the Far North $(\mathrm{p}<0.05)$

\begin{tabular}{|l|c|c|c|c|c|}
\hline $\begin{array}{c}\text { Temperament } \\
\text { trait }\end{array}$ & Groups by BI & BV & SV-2 & SV-1 & TI \\
\hline \multirow{2}{*}{ Activity } & Q & & & & -0.56 \\
\cline { 2 - 6 } & In & & & & 0.61 \\
\hline \multirow{2}{*}{ Rhythm } & $\mathrm{Q}$ & & & & -0.63 \\
\hline \multirow{2}{*}{ Mood } & In & & & & 0.56 \\
\cline { 2 - 6 } & Q & 0.53 & 0.55 & 0.46 & -0.54 \\
\hline \multirow{2}{*}{ Attention } & Q & -0.62 & & -0.66 & 0.64 \\
\cline { 2 - 6 } & In & 0.64 & 0.65 & 0.56 & -0.7 \\
\hline
\end{tabular}

in the Far North whose behaviour is characterized by a low index of behaviours - the "quiet" children and the "plastic" children, whose temperament is characterized by the average values of the strength index of developed behaviour stereotypes.

What is the mechanism and physiological significance of the detected patterns of a relationship between temperament traits of the child's personality, individual health and functional indices of cardio-respiratory system? The existing concept of a "range of adaptation" comes from evaluation of the ability of functional systems to change their characteristics to provide homeostasis in the implementation of adaptive mechanisms, including the way through the change of behaviour regimes. In this regard, our results confirm the recent series of assumptions that temperament refers to individual differences in the excitability of behavioural and physiological systems, as well as in behavioural and neural mechanisms of reactivity modulation (Karavaeva E.N., Soldatova O.G., Pats Iu.S., Savchenkov Iu.I., 2011).

Thus, our study suggests that "quiet" children in the Far North, whose temperament is characterized by a low behaviour index, are marked by the domination of a parasympathetic part of heart rate regulation at rest, the most optimal ratio between the autonomic and central heart rate regulation, and the higher functional indices of external respiration. This is a factor that contributes to a more economical and effective level of body functioning, adaptive processes and the state of individual health in children of junior school age in the Far North with a low behaviour index.

\section{References}

Baranov, A.A., Kuchma, V.R. \& Rapoport, I.K. (2011). Strategiia “'Zdorov’e i razvitie podrostkov Rossii” kak instrument mezhdunarodnogo vzaimodeistviia $v$ okhrane zdorov'ia detei. [The strategy "Health and Development of Adolescents in Russia" as an instrument of international cooperation in the protection of children's health]. Russian Journal of Pediatrics, 4, 12-18.

Baranov, A.A., Kuchma, V.R. \& Sukhareva, L.M. (2009). Sostoianie zdorov'ia sovremennykh detei i podrostkov i rol' mediko-sotsial'nykh faktorov $\mathrm{v}$ ego formirovanii. [The state of health of today's children and adolescents and the role of medical and social factors in its formation]. Bulletin of the Russian Academy of Medical Sciences, 5. 6-10. 
Bardetskaya Ya. V. \& Potylitsyna V.Yu. Osobennosti mekhanizmov reguliatsii vegetativnykh funktsii u mladshikh shkol'nikov s raznymi VP-tipami temperamenta. [Features of the mechanisms of regulation of vegetative functions in junior schoolchildren with different types of temperament]. Collection of scientific articles of the international scientific-practical conference held on March 2829, 2014. St. Petersburg Institute of Project Management. St. Petersburg, KultInformPress, 2014, pp. 18-21.

Bardetskaya Ya. V. \& Potylitsyna V.Yu. (2013). Psikhosomaticheskie osobennosti i uroven' zdorov'ia u detei mladshego shkol'nogo vozrasta s raznoi vyrazhennost'iu temperamental'nykh chert [Psychosomatic features and the health state of junior schoolchildren with different temperamental traits]. Journal of Siberian Federal University. Humanities \& Social sciences, 6(10), 1479-1491.

Bardetskaya Ya. V. \& Potylitsyna V.Yu. Stress, adaptatsiia i bolezn' [Stress, adaptation and disease]. Methodical development for independent work of students enrolled in undergraduate and graduate programs in 050400 "psycho-pedagogical education”. Ed. prof. S.N. Shilov. Krasnoyarsk State Pedagogical University named after V.P. Astaf'ev, 2013. 15 p. http://elib.kspu.ru/document/5687.

Chagaeva, N.V., Popova, I.V., Tokarev, A.N., Kashin, A.V. \& Beliakov, V.A. (2011). Sravnitel'naia kharakteristika fiziometricheskikh pokazatelei fizicheskogo razvitiia shkol'nikov. [Comparative characteristics of physiometric indices of physical development of schoolchildren]. Hygiene and sanitation, 2, 72-75.

Chekalova, N.G., Matveeva, N.A. \& Silkin, Iu.R. Metody issledovaniia i otsenki funktsional'nykh rezervov organizma detei i podrostkov: metodicheskie ukazaniia. [Methods of examination and evaluation of functional capacities of organisms of children and adolescents: guidelines]. Nizhny Novgorod, NizhGMA, 2009, 88 p.

Chekalova, N.G., Silkin, Iu.R., Shaposhnikova, M.V., Chekalova, S.A., Bogomolova, E.S., Glushenkova, D.A. \& Shcherbaneva, M.S. (2009). Otsenka urovnia funktsional'nykh rezervov organizma shkol'nikov. [Evaluation of the level of functional capacities of schoolchildren's organisms]. Bulletin of Russian University of Peoples' Friendship. Medicine. 4, 358-362.

Chekalova, S.A., Bogomolova, E.S., Leonov, A.V., Kuzmichev, Iu.G., Chekalova, N.G. \& Nazarova, M.M. (2009). Sanitarno-gigienicheskoe blagopoluchie shkoly kak faktor formirovaniia zabolevanii nervnoi sistemy u uchashchikhsia mladshikh klassov. [Hygiene and sanitary well-being of the school as a factor of nervous system diseases formation of junior schoolchildren]. Information Note "Health and Environment", 4, 22-25.

Evert, L.S., et al. (2009). Variabel'nost' serdechnogo ritma u mladshikh shkol'nikov s razlichnym urovnem adaptatsii $\mathrm{k}$ vysokim uchebnym nagruzkam. [Heart rate variability in junior schoolchildren with different level of adaptation to high teaching load]. Siberian medical review, 4, 32-35.

Evert, L.S., et al. (2013). Pokazateli psikhoemotsional'nogo statusa v otsenke adaptatsii detei severian k novym klimatogeograficheskim usloviiam prozhivaniia. [Indices of psychoemotional status in the evaluation of adaptation of children in the North to new climate-geographical conditions of living]. Bulletin of new medical technologies, 20(2).

Dedkova, L.S. Analiz urovnia uchashchikhsia obshcheobrazovatel'nykh uchrezhdeniiakh Nenetskogo avtonomnogo okruga $\mathrm{v}$ vozraste ot 7 do 18 let. [Analysis of the level of health of schoolchildren of educational institutions of the Nenets Autonomous District at age from 7 to 18]. 
New challenges of modern medicine: materials of the $3^{\text {rd }}$ International scientific Conference. (SaintPetersburg, December 2014). St. Petersburg, Zanevskaia square, 2014, pp. 90-95.

Dziatkovskaia, E.N. (2011). Zdorov'esberegaiushchii resurs metodicheskoi sistemy. [Health saving resource of methodical system]. Pedagogy, 1, 25-33.

Igisheva, L.N. (2008). Informatsionnye sistemy v kompleksnoi otsenke i prognoze sostoianiia zdorov'ja detei shkol'nogo vozrasta [Information systems in integrated assessment and forecast of the health condition of schoolchildren. Mother and child in Kuzbass, 1, 6-10.

Il'ina, I.V. (2012). Proektirovanie deiatel'nosti shkoly zdorov'ia na osnove tehnologii vosstanovitel'noi meditsiny [Activity development of health-based school on the basis of regenerative medicine technologies]. Bulletin of new medical technologies, 19(3), 180-181.

Iliukhina, V.A. (2011). Preemstvennost' i perspektivy razvitiia issledovanii v oblasti sistemnointegrativnoi psikhofiziologii funktsional'nykh sostojanii i poznavatel'noi deiatel'nosti [Continuity and prospects of research development in the field of system-integrative neuroscience of functional states and cognitive activity]. Human Physiology, 37(4), 105-123.

Karavaeva, E.N., Soldatova, O.G., Pats, Iu.S. \& Savchenkov, Iu.I. (2011). Osobennosti bioelektricheskoi aktivnosti golovnogo mozga i serdechnogo ritma u lits $\mathrm{s}$ razlichnoi stepen'iu povedencheskoi aktivnosti i emotsional'nosti [Features of bioelectric activity of brain and heart rate of patients with varying degrees of behavioral activity and emotionality]. Bulletin of the South Ural State University. Education, health, physical culture, 20(237), 18-21.

Khabarova, I.V. \& Shilov, S.N. (2012). Osobennosti aktivatsionnykh protsessov lobnoi kory golovnogo mozga i temperamental'nykh kharakteristik u mladshikh shkol'nikov s zaderzhkoi psikhicheskogo razvitiia [Features of activation processes of the frontal cortex of the brain and temperament traits of junior schoolchildren with mental retardation]. Defectology, 3, 52-59.

Khuras'kina, N.V., Aleksandrova, L.A. \& Chernerova, L.F. (2010). Vozrastnaia dinamika reguliatsii serdechnogo ritma u uchashchikhsia [Age dynamics of heart rhythm regulation of schoolchildren]. Bulletin of the Chuvash State Pedagogical University named after I.Ia. Iakovlev, 4, 204-209.

Kolpakov, V.V., Bespalova, T.V., Tomilova, E.A., Lar'kina, N.Iu., Mamchits, E.V., Chernogrivova, M.O. \& Kopytov, A.A. (2011). Funktsional'nye rezervy i adaptivnyi potentsial lits s razlichnym urovnem privychnoi dvigatel'noi aktivnosti [Functional reserves and adaptive potential of persons with different levels of habitual physical activity]. Human Physiology, 37(1), 105-117.

Kolpakov, V.V., Bespalova, T.V., Tomilova, E.A., Shtork, T.E., Mamchits, E.V., Lar'kina, N.Iu. \& Tkachuk, A.A. (2011). Sistemnyi analiz individual'no-tipologicheskikh osobennostei organizma. [Systems analysis of individual-typological characteristics of the organism]. Human Physiology, 37(6), 111-124.

Kolpakov, V.V., Bespalova, T.V., Lar'kina, N.Iu., Lebedeva, K.A., Tomilova, E.A. \& Belova, T.F. (2009). The concept of typological variability of physiological individuality: III. Psychophysiological characteristics of functional types differing in habitual physical activity. Human Physiology, 35(5), 600-611.

Kondakova, O.E., Gezalova, N.V., Shilov, S.N. \& Kozhevnikov, V.N. (2013). Tipy temperamenta i urovni aktivnosti lobnoi kory u mladshikh shkol'nikov s trudnostiami obucheniia [Types of temperament and levels of activity of the frontal cortex in primary school children with learning disabilities]. Bulletin of the Krasnoyarsk State Pedagogical University, 2, 155-159. 
Kopytova, N.S. \& Gudkov, A.B. (2007). Sezonnye izmeneniia funktsional'nogo sostoianiia sistemy vneshnego dykhaniia u zhitelei Evropeiskogo Severa Rossii [Seasonal changes in the functional state of the system of external respiration in the residents of the European North of Russia]. Human Ecology, 10 .

Krivoshchekov, S.G. Psikhofiziologicheskie mekhanizmy adaptatsii i dezadaptatsii na Severe. [Psychophysiological mechanisms of adaptation and disadaptation in the North]. S.G. Krivoshchekov. $13^{\text {th }}$ International Congress on Circumpolar Medicine. Novosibirsk, 2006, p. 6.

Kulikov V.P., Bezmaternykh, L.E. \& Kozlov, S.D. Programmnyi kompleks kolichestvennoi diagnostiki zdorov'ia "Khelmi - test 7-10 let" [The program complex of quantitative diagnosis of health "Helmy - test of 7-10 year-old children"].

Kulikov, V.P., Doronina, N.L. \& Gatal'skii, K.K. (2008). Reaktsiia mozgovoi gemodinamiki na fizicheskuiu nagruzku nizkoi intensivnosti [Reaction of cerebral hemodynamics to low-intensity physical activity]. Russian physiological journal named after I.M. Sechenov, 94(7), 790-798.

Kuchma, V.R., Zvezdina, I.V. \& Zhigareva, N.S. (2008). Mediko-sotsial'nye aspekty formirovaniia zdorov'ia mladshikh shkol'nikov [Medical and social aspects of health formation of junior schoolchildren]. Current Pediatrics issues, 7(4), 9-12.

Kushnir, S.M., Struchkova, I.V., Makarova, I.I. \& Antonova, L.K. (2012). Sostoianie vegetativnoi reguliatsii serdechnogo ritma u zdorovykh detei $\mathrm{v}$ razlichnye periody detstva [Autonomic regulation condition of heart rate in healthy children at different periods of childhood]. Scientific statements of Belgorod State University. Natural Sciences, 18(3), 161-165.

Maiorov, R.V. (2012). Emotsional'no-povedencheskie i immunologicheskie parametry u chasto boleiushhikh detei [Emotional-behavioral and immunological parameters of sickly children. Verkhnevolzhskii medical journal, 10(4), 17-20.

Manchuk, V.T., Soldatova, O.G. \& Potylitsyna V.Yu. (2009). Osobennosti funktsional'nogo sostoianiia i reguliatsii kardiorespiratornoi sistemy u detei s raznymi VP-tipami temperamenta [Features of functional condition and regulation of the cardio-respiratory system of children with different temperament traits indices]. Bulletin of the Siberian Branch of the Russian Academy of Medical Sciences, 5, 53-60.

Mikhailov, N.A. (2011). Vzaimodeistvie sily nervnykh protsessov, funktsional'noi asimmetrii i variabel'nosti serdechnogo ritma [The interaction of strength of nervous processes, functional asymmetry and heart rate variability]. Bulletin of the Chuvash State Pedagogical University named after I.Ia. Yakovlev, 4-1, 65-71.

Ostanin, S.A., Volkov, V.I., Kulikov, V.P. \& Kolosov, D.A. (2008). Metod kompensatsii variabel'nosti serdechnogo ritma pri analize sfigmogrammy [Compensation method of heart rate variability in the sphygmogram analysis]. Medical equipment, 6, 7-9.

Petrosian, E.Iu. \& Savchenko Iu.I. (2009 a). Metod opredeleniia chastnykh VP-tipov temperamenta po rezul'tatam issledovaniia ego chert po A. Tomasu [Method of determining particular temperament traits index types based on the results of research of its features according to A. Thomas]. Siberian Medical Review. Quarterly Journal of Medicine, 5(5), 35-38.

Petrosian, E.Iu. \& Savchenko Iu.I. (2009 b). Sravnitel'naia kharakteristika obshchikh i chastnykh tipov temperamenta [Comparative characteristics of general and specific types of temperament]. Siberian Medical Review. Quarterly Journal of Medicine, 58(4), 20-24. 
Petrosian, E.Iu. \& Savchenko Iu.I. (2009 c)Tipy vozrastnoi dinamiki nekotorykh chert temperamenta. [Types of age dynamics of some features of temperament]. Bulletin of Tomsk State Pedagogical University, 4, 65-70.

Petrosyan, E.Iu., Savchenko, Yu.I, Domracheva, M.Ia. \& Domrachev, A.A. Pat. Rossiiskaia Federatsiia MPK 7 A 61 v 5/16. Sposob ATSP-tipirovaniia chert temperamenta. opubl. 20.12.2005 [Pat. The Russian Federation IPC 7A 61 5/16. The method of ADC-typing of temperament traits, published on 12.20.2005].

Popova, O.N., Glebova, N.A. \& Gudkov, A.B. (2008). Kompensatorno-prisposobitel'naia perestroika sistemy vneshnego dykhaniia u zhitelei Krainego Severa [Compensatory-adaptive restructuring of the system of external respiration in the residents of the Far North]. Human Ecology, 10.

Popova, O.N. \& Gudkov, A.B. (2012). Adaptivnye reaktsii vneshnego dukhaniia u zhitelei Evropeiskogo Severa i Zapoliar'ia [Adaptive reactions of external respiration in residents of the European North and The Subarctic]. Electronic Scientific-Educational Bulletin "Health and education in the $21^{s t}$ century", 14(11).

Potylitsyna V.Yu. Vliianie chert temperamenta na kliniko-fiziologicheskie pokazateli funktsional'nykh sistem detei mladshego shkol'nogo vozrasta. [Influence of temperament traits on clinical and physiological measures of functional systems of junior schoolchildren]. Abstract of PhD thesis in Medical Sciences. Krasnoyarsk, 2008.

Potylitsyna V.Yu. \& Bardetskaya Ya. V. (2013). Funktsional'noe sostoianie i reguljatsii kardiorespiratornoi sistemy u detei mladshego shkol'nogo vozrasta s raznymi tipologicheskimi osobennostiami temperamenta [Functional state and regulation of the cardio-respiratory system of junior schoolchildren with different typological temperament traits]. Siberian Journal of Special Education. No. of state registration 0421200160, 1(9), 103-117. URL: http: // sibsedu. kspu.ru

Pshennikova, M.G. (2011). Rol' geneticheskikh osobennostei organizma v ustoichivosti k povrezhdaiushchim vozdeistviiam i v zashchitnykh effektakh adaptatsii [Role of genetic characteristics of the organism in resistance to damaging effects and in protective effects of adaptation]. Pathological Physiology and Experimental Therapy, 4, 7-16.

Riasik, Iu.B., Tsirkin, V.I. \& Trukhina, S.I. (2010). Polovye osobennosti sostoianiia vegetativnoi nervnoi sistemy u mladshikh shkol'nikov s uchetom vida funktsional'noi asimmetrii polusharii i nalichiia vegetativnykh narushenii [Gender features of the autonomic nervous system state of junior schoolchildren with regard to the kind of functional asymmetry of hemispheres and presence of autonomic disorders]. Viatskii Medical Bulletin, 2, 36-41.

Savilov, E.D. \& Il'ina, S.V. (2012), Osobennosti infektsionnoi patologii detskogo naseleniia v usloviiakh tekhnogennogo zagriazneniia okruzhaiushhei sredy [Features of infectious diseases of child population in terms of man-made environmental pollution]. Epidemiology and vaccination, 1 , 58-63.

Savchenkov, Iu.I. \& Petrosian, E.Iu. (2009). K voprosu o plastichnosti svoistv temperamenta [On the plasticity of temperament traits]. Siberian psychological journal, 32, 46-51.

Savchenkov, Iu.I., Soldatova, O.G. \& Shilov, S.N. Vozrastnaia fiziologiia (fiziologicheskie osobennosti detei i podrostkov): ucheb. posobie dlia stud. ped. Vuzov. [Age physiology (physiological 
characteristics of children and adolescents): textbook for students of Pedagogical Universities]. Moscow, VLADOS, 2013. 143 p.

Sapozhnikov, E.N., Shlyk, N.I., Shumikhina, I.I. \& Kirillova, T.G. (2012). Tipologicheskie osobennosti variabel'nosti serdechnogo ritma u shkol'nikov 7-11 let v pokoe i pri zaniatiiakh sportom [Typological features of heart rate variability of 7-11-year-old schoolchildren at rest and at exercise]. Bulletin of Udmurt University, 6-2, 79-88.

Shesterikova, N.V. \& Tokarev, S.A. Populiatsionnaia otsenka zdorov'ia i serdechno-sosudistogo riska prishlogo gorodskogo naseleniia Krainego Severa. [Population assessment of health and cardiovascular risk in immigrant urban population in the Far North]. Ed. by Corresponding member of the Academy of Medical Sciences, Professor A.A. Buganov. Omsk: Publishing House of the OSMA, 2004. $142 \mathrm{p}$.

Shilov, S.N., Soldatova, O.G. \& Nalivaiko, N.D. (2014). Temperamental'nye cherty lichnosti rebenka, kak faktor, opredeliaiushchii rezerv zdorov'ia. [Temperamental characteristics of the child's personality as determinant of health reserve]. Bulletin of Novosibirsk State Pedagogical University, 1, 89-100.

Shlyk, N.I. \& Sapozhnikov, E.N. (2008). K voprosu o metodicheskikh podkhodakh $k$ analizu variabel'nosti serdechnogo ritma. [On the question of methodological approaches to analysis of heart rate variability]. Pedagogical-psychological and medical-biological problems of physical training and sports, 1(6), 33-40.

Shlyk, N.I., Sapozhnikova, E.N., Kirillova, T.G. \& Semenov, V.G. (2009). Typological characteristics of the functional state of regulatory systems in schoolchildren and young athletes (according to heart rate variability data). Human Physiology, 35(6), 730-738.

Slobodskaia, H.R. \& Akhmetova, O.A. (2010). Personality development and problem behavior in Russian children and adolescents. International Journal of Behavioral Development, 34(5), 441-451.

Slobodskaia, E.R., Akhmetova, O.A., Kuznetsova, V.B. \& Rippinen, T.O. (2012).Vzaimodeistvie chuvstvitel'nosti k podkrepleniiu i semeinykh faktorov blagopoluchiia detei i podrostkov [Interaction of sensitivity to reinforcement and family factors of well-being of children and adolescents]. Psychological Journal, 33(4), 60-69.

Soldatova, O.G., Pats, Iu.S. \& Savchenkov, Iu.I. (2010). Nespetsificheskaia rezistentnost' organizma i moshchnost' medlenno volnovykh kolebatel'nykh protsessov u lits s rannei vyrazhennost'iu chert temperamenta [Non-specific resistance of body and power of slow wave oscillation processes of persons with early intensity of temperament traits]. Siberian medical review, 65(5), 37-42.

Soldatova, O.G., Pats, Iu.S., Savchenko, Iu.I. \& Medvedev, V.S. (2012). Sootnoshenie svoistv temperamenta s pokazateliami funktsional'noi aktivnosti zheludochno-kishechnogo trakta [The ratio of temperament traits with indicators of functional activity of the gastrointestinal tract]. Siberian medical review, 75(3), 54-56.

Soldatova, O.G., Shilov, S.N. \& Potylitsyna V.Yu. (2008). Vzaimosviaz' osobennostei temperamenta $s$ nespetsificheskoi rezistentnost'iu organizma i urovnem zdorov'ia [Relationship of temperament characteristics with non-specific resistance of organism and standard of health]. Neurological Journal (Journal named after V.M. Bekhterev), XL(1), 10-13. 
Tokarev, S.A. \& Buganov, A.A. (2007). Populiatsionnaia otsenka faktorov, formiruiushchikh zdorov'e detei Krainego Severa [Population assessment of factors that shape health of children in the Far North]. Current Pediatrics, 6(1).

Ushakov, I.B., Orlov, O.I., Baevskii, R.M., Bersenev, E.Iu. \& Chernikova, A.G. (2013). Novye tekhnologii otsenki zdorov'ia u prakticheski zdorovykh liudei [New health assessment technologies for almost healthy people]. Russian physiological journal named after I.M. Sechenov, 99(3), 313-319.

Varshal, A.V. \& Slobodskaia, E.R. (2013). Adaptaciia “interv'iu o praktike vospitaniia” dlia roditelei i perspektivy ego ispol'zovaniia pri diagnostike i korrektsii problem povedeniia u detei [Adaptation of "interview about the practice of education" for parents and the prospects for its use in the diagnosis and correction of behavior problems in children]. Review of Psychiatry and Medical Psychology named after V.M. Bekhterev, 1, 25-31.

\title{
Состояние индивидуального здоровья, кардиореспираторной системы младших школьников Крайнего Севера с разной выраженностью темпераментальных черт
}

\author{
Я.В. Бардецкая, В.Ю. Потылицина \\ Красноярский государственный педагогический \\ университет им. В.П. Астафьева \\ Россия 660049, Красноярск, ул. Ады Лебедевой, 89
}

Проведена интегративная оценка здоровья с определением показателей сантивности u пативности, исследовалась вариабельность сердечного ритма (ВРС) и функция внешнего дыхания у младших школьников Крайнего Севера с разной выраженностью темпераментальных черт. Установлено наличие у младших икольников Крайнего Севера взаимосвязи типологических особенностей темперамента с уровнем здоровья, механизмами регуляиии сердечного ритма и функииональными показателями внешнего дыхания. У младших школьников Крайнего Севера, темперамент которых характеризуется низкой выраженностью поведенческих проявлений, более высокие адаптивные резервы, функииональные показатели внешнего дыхания и преобладает парасимпатическая регуляция сердечного ритма. Таким образом, результаты исследования показали: формирование типов темперамента происходит уже в младшем школьном возрасте, что может повлиять на эффективность адаптационных реакиий организма детей, проживающих в условиях Крайнего Севера, и на состояние их индивидуального здоровья.

Ключевые слова: темперамент, младшие школьники Крайнего Севера, уровень здоровья, кардиореспираторная система.

Исследование проведено в рамках выполнения гранта РГНФ и Красноярского края 151624007 на тему: «Комплексные исследования коренных малочисленных народов Арктической зоны Восточной Сибири в области фундаментальной медицины, дистанционной педагогики, соииально-культурной и экономической деятельности».

Научная специальность: 13.00.00 - педагогические науки, 19.00.00-nсихологические науки. 